\title{
New technologies for diabetes: a review of the present and the future
}

\author{
Neesha Ramchandani ${ }^{1}$ and Rubina A Heptulla $a^{1,2^{*}}$
}

\begin{abstract}
This review summarizes the technologies in use and in the pipeline for the management of diabetes. The review focuses on glucose meters, continuous glucose monitoring devices, insulin pumps, and getting clinicians connected to technologies. All information presented can be found in the public domain, and was obtained from journal articles, websites, product review tables in patient publications, and professional conferences. The technology concerns, ongoing development and future trends in this area are also discussed.
\end{abstract}

Keywords: Diabetes technology, Continuous glucose monitoring, Insulin pump, Blood glucose meter, New therapies, Inhaled insulin, Insulin patch, Insulin pill, SmartInsulin

This review summarizes currently available glucose monitoring and insulin delivery devices and discusses their advantages and disadvantages. It also highlights the "next generation" products under different stages of development. All information was obtained from the public domain.

\section{Blood glucose monitoring devices}

Optimal diabetes management relies on accurate glucose monitoring devices. Advances in blood glucose (BG) monitoring technology have resulted in improved accuracy, smaller required blood volumes, and the ability to transfer data between the BG meter and insulin delivery devices.

\section{A. Capillary blood glucose monitoring}

\section{Devices}

Current home BG meters use capillary blood samples ranging from 0.3-1.5 microliters [1]. The sample is analyzed using either a glucose oxidase or a glucose dehydrogenase reaction. Some strips use the enzymatic/ biosensor reaction alone, while others convert the enzymatic reaction into an electrochemical signal first [2]. Although whole blood is used, the meter output is calibrated to provide results that correlate with plasma

\footnotetext{
* Correspondence: rubhep@gmail.com

'The Children's Hospital at Montefiore, Division of Pediatric Endocrinology \& Diabetes, 3415 Bainbridge Ave, Bronx, NY 10467, USA

${ }^{2}$ Albert Einstein College of Medicine, Division of Pediatric Endocrinology, Bronx, NY 10461, USA
}

glucose values. Subtle differences exist among meter performances, such as the ability to withstand temperature extremes and accuracy at higher altitudes. Additionally, certain substances interfere with test strip accuracy. An altered hematocrit will falsely alter the BG in the same direction. Maltose, ascorbate, and acetominaphen interfere with the enzymatic reaction on the test strip, greatly affecting the accuracy of the BG reading $[3,4]$. A combination of interfering substances can have up to a $193 \%$ impact on the accuracy of the BG reading [3]. Despite slight variations in meter advantages, all of the currently FDA approved meters are within 10-15\% of actual laboratory plasma glucose values. A reference table of currently available BG meters is published by Diabetes Health every January [1].

Enhanced devices Meter capability is continuously being enhanced. The Freestyle InsuLinx, approved in Europe in 2011, allows patients to program their insulinto-carbohydrate ratio, correction factor, and target BG into the meter. This information enables the meter to recommend the next insulin dose based on BG and carbohydrate intake [5]. A simplified version of the Freestyle InsuLinx, FDA approved in March 2012 and available for use in the US, works as a meter with a touch screen electronic logbook without bolus calculation capabilities. The One Touch Verio IQ meter, approved in the US and Canada in February 2012, recognizes 
patterns of hypo- or hyperglycemia and alerts the user to them [6].

Cell phone-enhanced meters The LG KP8400 cell phone add-on has been available in Korea since 2002, and the Infopia LG Glucophone/JVAGO 5965 has been advertised for the US market since 2008. The meter piece is attached to the back of the phone, near the battery pack. Readings are displayed on the cell phone and can be uploaded to an online database [7]. This device is currently unavailable in the US. The European, Bluetooth-enabled GlucoTel system enables wireless transmission of glucose values from a BG meter to a web-based logbook using the individual's mobile phone as the communication hub [8]. The iBG Star meter and app, recently developed by Sanofi-Aventis, allows certain smartphones (iPhone or iTouch) to serve as the BG meter [9].

Plug-and-play devices The iBG Star meter is one type of plug-and-play device, as the meter must be plugged into a smartphone in order to function. The smartphone serves as this meter's screen. Another type of plug-andplay device is the Ascensia Contour USB meter, which is a blood glucose meter that also has a USB drive and contains software within it so BG data can be downloaded to a computer without the need of additional software/cables.

Combination devices In the past, Novo Nordisk partnered with Lifescan and created a device called the InDuo, which was the world's first combined BG meter and insulin delivery device. The meter debuted in 2002, and for undisclosed reasons was discontinued in 2006 [10]. BG meters that double as remote controls for insulin pumps are currently available (see below). After a several year hiatus, BG meter/insulin delivery combination devices are now being revisited [11].

Communication with other devices Radiofrequency technology is used to transfer BG data to insulin pumps; all currently available insulin pumps are enabled with this feature. The Medtronic MiniMed pumps' associated meters (One Touch UltraLink and Ascensia Contour next link) send BG values to the pump to be incorporated into the calculation of the insulin dose. The Animas One Touch Ping, OmniPod PDM, and Accu-Chek Aviva Combo meters serve as the remote control to the pump itself. The Animas Vibe and Medtronic MiniMed Paradigm systems receive information from their paired real-time continuous glucose monitoring transmitters and display the information on the pump's screen.

\section{Future directions/under development}

The newest BG monitoring devices on the market and some of those under development appear in Table 1 [5,6,9,12-23].

Non-invasive glucose monitoring is the goal of the future. Past attempts at non-invasive glucose monitoring failed to reliably separate glucose values from noise without an actual blood sample. Scientific and technological progress have allowed for other, different techniques to be tried, which overcome difficulties faced in the past [24]. Some of the devices under development are truly non-invasive, while others require something to be injected or implanted under the skin to enable glucose detection (Table 1, [15-23]).

\section{Connecting meters to clinicians and caregivers}

GlucoMON, a system developed by Diabetech in 2006, connects One Touch Ultra BG meters to clinicians and caregivers in real time, using 3G cell phone networks to transmit the data to cell phones, e-mails, and pagers $[25,26]$. The GlucoTel system wirelessly sends BG's to a web-based logbook using the patient's mobile phone as the server [8]. The newly available Telcare system uses $3 G$ cell phone networks to enable two-way communication between the meter and smartphones and its webbased server. Clinicians can access their patients' information through the website and can customize messages that appear on their patients' meters every time a BG is checked [13,14]. Other online diabetes management software exists, including Cerner [27], Diasend [28], and Carelink [29]. These systems all require the user to actively upload their devices (instead of data being sent automatically). The reports can be seen by patients and clinicians alike provided the clinician has access to the patient's report. There are some limitations as to which devices can be uploaded into these programs. Carelink can only be used for the Medtronic MiniMed insulin pumps, glucose sensors, and related BG meters [29]; Cerner and Diasend allow for upload of the Animas insulin pump and most commonly used BG meters $[27,28]$.

In the office, clinicians can download data from BG meters using proprietary software and cables. The programs can be installed on individual computers or networked to several computers, and comprehensive reports can be both printed and saved. If patients use these programs at home, reports can be e-mailed to their clinicians for review.

\section{B. Continuous glucose monitoring (CGM) Basic CGM}

Real-time continuous glucose monitoring (RT-CGM) allows for continuous measurement of interstitial glucose concentrations. A small, enzyme-coated filament 
Table 1 Innovative new blood glucose monitors (existing \& under development)

\begin{tabular}{|c|c|c|c|c|c|c|}
\hline Meter & Company & FDA/CE status & Meter type & $\begin{array}{c}\text { Outstanding } \\
\text { feature(s)/How it works }\end{array}$ & Pros & Cons \\
\hline \multicolumn{7}{|c|}{ Invasive BG Monitors } \\
\hline iBG Star & $\begin{array}{l}\text { Sanofi Aventis } \\
\text { \& AgaMatrix }\end{array}$ & $\begin{array}{l}\text { FDA: approved } \\
\text { December } \\
2011 \text { CE: } \\
\text { approved } \\
\text { Spring } 2011 \\
\end{array}$ & $\begin{array}{l}\text { Plug-and- } \\
\text { play } \\
\text { (hardware), } \\
\text { invasive }\end{array}$ & $\begin{array}{l}\text { Meter can be integrated into } \\
\text { iPhone or iTouch }\end{array}$ & $\begin{array}{l}\text { Integrated with } \\
\text { smartphone }\end{array}$ & $\begin{array}{l}\text { Only integrated with } \\
\text { iPhone/iTouch; } \\
\text { requires a blood } \\
\text { sample }\end{array}$ \\
\hline Telcare & Telcare Inc. & $\begin{array}{l}\text { FDA: approved } \\
\text { August } 2011 \\
\text { CE: unknown }\end{array}$ & $\begin{array}{l}\text { Multimedia, } \\
\text { invasive }\end{array}$ & $\begin{array}{l}\text { Uses } 3 G \text { cellular service to } \\
\text { communicate with smartphone } \\
\text { apps and its own web-based } \\
\text { software; gives feedback to user } \\
\text { with every BG reading; can re- } \\
\text { order supplies through meter }\end{array}$ & $\begin{array}{l}\text { Easy to send data to } \\
\text { logs and clinicians, gives } \\
\text { feedback to user with } \\
\text { every BG, easy to } \\
\text { reorder supplies }\end{array}$ & $\begin{array}{l}\text { Requires a blood } \\
\text { sample }\end{array}$ \\
\hline $\begin{array}{l}\text { Freestyle } \\
\text { InsuLinx }\end{array}$ & Abbott & $\begin{array}{l}\text { FDA: modified } \\
\text { version } \\
\text { approved } \\
\text { March } 2012 \text { CE: } \\
\text { approved May } \\
2011\end{array}$ & $\begin{array}{l}\text { Smart } \\
\text { meter, } \\
\text { invasive }\end{array}$ & $\begin{array}{l}\text { Meter with bolus calculator } \\
\text { within }\end{array}$ & $\begin{array}{l}\text { No need to calculate } \\
\text { bolus dose }\end{array}$ & $\begin{array}{l}\text { Requires a blood } \\
\text { sample }(0.3 \mu l)\end{array}$ \\
\hline $\begin{array}{l}\text { One Touch } \\
\text { Verio IQ }\end{array}$ & Lifescan & $\begin{array}{l}\text { FDA: approved } \\
\text { Feb. } 2012 \text { CE: } \\
\text { unknown }\end{array}$ & $\begin{array}{l}\text { Smart } \\
\text { meter, } \\
\text { invasive }\end{array}$ & $\begin{array}{l}\text { Meter with pattern recognition } \\
\text { capabilities. Also has a } \\
\text { rechargeable battery. }\end{array}$ & $\begin{array}{l}\text { Prompts user when } \\
\text { patterns of } \\
\text { hypoglycemia or } \\
\text { hyperglycemia occur, so } \\
\text { medication adjustments } \\
\text { can be made }\end{array}$ & $\begin{array}{l}\text { Requires a blood } \\
\text { sample }(0.4 \mu \mathrm{l})\end{array}$ \\
\hline $\begin{array}{l}\text { Glucose } \\
\text { Monitor } \\
\text { Tattoo }\end{array}$ & $\begin{array}{l}\text { Massachusetts } \\
\text { Institute of } \\
\text { Technology, } \\
\text { Northeastern } \\
\text { University }\end{array}$ & $\begin{array}{l}\text { FDA \& CE: pre- } \\
\text { submission }\end{array}$ & $\begin{array}{l}\text { Minimally } \\
\text { invasive }\end{array}$ & $\begin{array}{l}\text { Superficial, biocompatible tattoo } \\
\text { containing special nanosensors } \\
\text { that fluoresce in the presence of } \\
\text { glucose }\end{array}$ & $\begin{array}{l}\text { Non-invasive BG } \\
\text { monitoring, very small } \\
(2 \mathrm{~mm}) \text {, fluorescence } \\
\text { reader is iPhone } \\
\text { compatible }\end{array}$ & $\begin{array}{l}\text { Tattoo needs to be } \\
\text { replaced weekly; } \\
\text { brightness not yet } \\
\text { correlated to specific } \\
\text { BG values; will not be } \\
\text { available soon }\end{array}$ \\
\hline \multicolumn{7}{|c|}{ Non-Invasive Glucose Monitors } \\
\hline GlucoTrack & $\begin{array}{l}\text { Integrity } \\
\text { Applications }\end{array}$ & $\begin{array}{l}\text { FDA: not yet } \\
\text { approved CE: } \\
\text { approved } 2009\end{array}$ & $\begin{array}{l}\text { Non- } \\
\text { invasive }\end{array}$ & $\begin{array}{l}\text { Uses ultrasound, conductivity, } \\
\text { and heat capacity in an ear clip } \\
\text { sensor to check BG's }\end{array}$ & Non-invasive & $\begin{array}{l}\text { Concerns about } \\
\text { accuracy in real-life } \\
\text { settings }\end{array}$ \\
\hline $\begin{array}{l}\text { Portable } \\
\text { blood } \\
\text { glucose } \\
\text { meter }\end{array}$ & $\begin{array}{l}\text { Grove } \\
\text { Instruments }\end{array}$ & $\begin{array}{l}\text { FDA \& CE: } \\
\text { unknown }\end{array}$ & $\begin{array}{l}\text { Non- } \\
\text { invasive }\end{array}$ & $\begin{array}{l}\text { Uses its patented Optical Bridge } \\
\text { technology to read glucose } \\
\text { through a finger or earlobe in } \\
<20 \text { seconds }\end{array}$ & Non-invasive & $\begin{array}{l}\text { Size of device } \\
\text { (company is working } \\
\text { on miniaturizing it) }\end{array}$ \\
\hline $\begin{array}{l}\text { Electronic } \\
\text { thumb-pad } \\
\text { sensor }\end{array}$ & $\begin{array}{l}\text { Baylor } \\
\text { University } \\
\text { (Texas) }\end{array}$ & $\begin{array}{l}\text { FDA \& CE: pre- } \\
\text { submission }\end{array}$ & $\begin{array}{l}\text { Non- } \\
\text { invasive }\end{array}$ & $\begin{array}{l}\text { Measures changes in } \\
\text { electromagnetic energy waves } \\
\text { passed through the skin to } \\
\text { detect BG }\end{array}$ & Non-invasive & Unknown \\
\hline $\begin{array}{l}\text { Near infrared } \\
\text { optical } \\
\text { spectroscopy }\end{array}$ & $\begin{array}{l}\text { Inlight } \\
\text { Solutions }\end{array}$ & $\begin{array}{l}\text { FDA \& CE: not } \\
\text { yet approved }\end{array}$ & $\begin{array}{l}\text { Non- } \\
\text { invasive }\end{array}$ & $\begin{array}{l}\text { Uses near infrared optical } \\
\text { spectroscopy and multivariate } \\
\text { analysis to measure glucose } \\
\text { through the skin }\end{array}$ & Non-invasive & Unknown \\
\hline $\begin{array}{l}\text { LighTouch } \\
\text { Technology }\end{array}$ & LighTouch & $\begin{array}{l}\text { FDA \& CE: not } \\
\text { yet approved }\end{array}$ & $\begin{array}{l}\text { Non- } \\
\text { invasive }\end{array}$ & $\begin{array}{l}\text { Light of a specific color is } \\
\text { projected into the user's fingertip } \\
\text { and the different colored light } \\
\text { that is reprojected from the } \\
\text { fingertip is measured }\end{array}$ & Non-invasive & $\begin{array}{l}\text { Unknown; device has } \\
\text { been in development } \\
\text { since } 1999\end{array}$ \\
\hline I-SugarX & $\begin{array}{l}\text { Freedom } \\
\text { Meditech }\end{array}$ & $\begin{array}{l}\text { FDA \& CE: not } \\
\text { yet approved }\end{array}$ & $\begin{array}{l}\text { Non- } \\
\text { invasive }\end{array}$ & $\begin{array}{l}\text { Measures the fluorescence of } \\
\text { glucose in the aqueous solution } \\
\text { of the eye }\end{array}$ & Non-invasive, quick test & $\begin{array}{l}\text { Must shine a light in } \\
\text { the eye (for }<1 \text { second) } \\
\text { to get a glucose } \\
\text { reading }\end{array}$ \\
\hline $\begin{array}{l}\text { Contact lens } \\
\text { CGM }\end{array}$ & $\begin{array}{l}\text { University of } \\
\text { Washington }\end{array}$ & $\begin{array}{l}\text { FDA \& CE: pre- } \\
\text { submission }\end{array}$ & $\begin{array}{l}\text { Non- } \\
\text { invasive }\end{array}$ & $\begin{array}{l}\text { Contact lens with additional } \\
\text { enhancements, including an } \\
\text { antenna, measures glucose } \\
\text { concentrations in tears and } \\
\text { sends the signal to a receiver }\end{array}$ & Non-invasive & $\begin{array}{l}\text { User must have a } \\
\text { normal tear } \\
\text { concentration; device } \\
\text { needs further } \\
\text { improvement to } \\
\text { work in humans }\end{array}$ \\
\hline
\end{tabular}


Table 1 Innovative new blood glucose monitors (existing \& under development) (Continued)

\begin{tabular}{|c|c|c|c|c|c|c|}
\hline \multicolumn{7}{|c|}{ Non-Invasive Continuous Glucose Monitors } \\
\hline $\begin{array}{l}\text { Symphony } \\
\text { tCGM } \\
\text { System }\end{array}$ & $\begin{array}{l}\text { Echo } \\
\text { Therapeutics }\end{array}$ & $\begin{array}{l}\text { FDA \& CE: } \\
\text { device in } \\
\text { development, } \\
\text { studies } \\
\text { ongoing }\end{array}$ & $\begin{array}{l}\text { Non- } \\
\text { invasive, } \\
\text { continuous } \\
\text { glucose } \\
\text { monitor }\end{array}$ & $\begin{array}{l}\text { Skin is prepped with Prelude } \\
\text { device to increase permeability } \\
\text { (stratum corneum is removed), } \\
\text { and a needle-free, wireless } \\
\text { transdermal sensor is placed on } \\
\text { the area }\end{array}$ & $\begin{array}{l}\text { Non-invasive; Gives a } \\
\text { glucose reading every } \\
1 \text { minute; Designed to } \\
\text { use in hospital critical } \\
\text { care settings }\end{array}$ & $\begin{array}{l}\text { Concerns about } \\
\text { possible side effects }\end{array}$ \\
\hline $\begin{array}{l}\text { Multisensor } \\
\text { Glucose } \\
\text { Monitoring } \\
\text { System }\end{array}$ & Biovotion AG & $\begin{array}{l}\text { FDA \& CE: } \\
\text { unknown }\end{array}$ & $\begin{array}{l}\text { Non- } \\
\text { invasive, } \\
\text { multisensor }\end{array}$ & $\begin{array}{l}\text { Uses optical sensors/impedance } \\
\text { spectroscopy to deliver } \\
\text { continuous information on } \\
\text { glucose variations }\end{array}$ & Non-invasive & Unknown \\
\hline
\end{tabular}

(<13 $\mathrm{mm}$ in length) inserted subcutaneously detects interstitial glucose through a glucose oxidase reaction. The electrochemical signal is transmitted to a receiver using radiofrequency, where it is converted into a glucose value. The receiver can be an insulin pump (Medtronic Paradigm system, Animas Vibe system) or it can be a stand-alone unit (DexCom, Freestyle Navigator, Medtronic Guardian). The Medtronic's iPro is a blinded system used by clinicians for diagnostic or research purposes. Sensor glucose values are updated every 1-5 minutes. Sensor electrodes can remain in the body for 3-7 days [30].

RT-CGM systems must be calibrated at regular intervals with a fingerstick BG value, both for accuracy and in order to continue giving the user information. Sensor glucose values are generally within $20 \%$ of actual BG values [30-36].

\section{Benefits}

RT-CGM is clinically useful in identifying post-prandial hyperglycemia, overnight hypoglycemia, hypoglycemia in those with hypoglycemia unawareness, and daily glucose trends. Studies show that patients with type 1 diabetes who use RT-CGM at least $60-70 \%$ of the time have significant improvements in glycemic control [37-44]. A recent study found sensor use even $41-60 \%$ of the time to have beneficial glycemic effects [45]. Early studies found that patients who are at least 25 years of age experienced the greatest benefits from RT-CGM use [37-41]. This was hypothesized to be due to increased RT-CGM use and better adherence to treatment in adults compared with children and adolescents [40]. Newer studies have shown glycemic benefits of RT-CGM in all age groups [46]. In a sample of pediatric patients, Ramchandani et al. [47] found that although only $21 \%$ of all subjects who had a sensor used it continuously, $76 \%$ of subjects who owned a sensor believed that using RT-CGM helped them to better manage their diabetes.

\section{Disadvantages}

The difficulty with RT-CGM is getting patients, especially children and adolescents, to use it on a regular basis for extended periods of time. In many, the frequency of RT-CGM use decreases over time, especially when patients experience frustration with the system. The major reasons cited for disuse of RT-CGM are that patients found it annoying, a hassle, and interfering with their lives. Those who stop using it do so because of problematic equipment, insurance issues, and inaccuracy [47]. These issues need to be addressed before RT-CGM is embraced more universally.

\section{Connecting CGM to clinicians}

Current CGM devices can be uploaded into devicespecific software programs and shared with clinicians either as PDF or Word documents (attached to an e-mail or sent by fax), as web-based reports (Medtronic MiniMed CGM devices only), or during an office visit. Glucose sensors can only be downloaded by proprietary programs, and CGM data fails to integrate with electronic medical record databases.

\section{Future directions/under development}

The goal of RT-CGM is to develop smaller, more accurate devices. Technologies under consideration include an enhanced transdermal system (Symphony tCGM, $[48,49])$, multiple optical sensors using impedance spectroscopy (Table 1, [50]), an optical fluorescence fiberoptic biosensor using fluorophore-labeled glucose/galactose binding protein technology [51] which is shown to be $>95 \%$ accurate in vitro [52], non-enzymatic glucose sensors based on nickel (II) oxide electrospun nanofibers [53] and nickel nanoparticles on carbon nanotubes [54], and a small $(3.6 \mathrm{~mm} \times 8.7 \mathrm{~mm})$ continuous osmotic injectable/implantable glucose sensor whose performance is reliable in vitro for up to four weeks [55]. Additionally, intravascular glucose sensors for use in the critical care setting in the hospital are in the works [56]. More accurate RT-CGM devices are needed and have great potential for use both with and without an artificial pancreas.

Connecting CGM to insulin delivery, including closedloop Some insulin pump companies have already 
connected glucose sensors to insulin delivery devices in the first steps towards an artificial pancreas. The Medtronic MiniMed Veo pump, available in Europe, Australia, and Canada, suspends basal insulin delivery for two hours if the sensor glucose is below a set level and the individual with diabetes fails to respond or the sensor glucose remains low for a given amount of time. Two insulin pump/glucose sensor devices are currently approved for patient use and many more are currently under development. The Juvenile Diabetes Research Foundation (JDRF)'s proposed steps towards development of the artificial pancreas include: 1) a sensoraugmented pump that will shut off for a specific amount of time when the user does not respond to a low glucose alarm, 2) a hypoglycemia minimizer that adjusts insulin delivery when a low glucose is predicted, 3) a hypoglycemia and hyperglycemia minimizer that will decrease insulin delivery if a low glucose is predicted and increase it if a high glucose (e.g., $>200 \mathrm{mg} / \mathrm{dl}$ ) is predicted, 4) a hybrid closed loop, where the user manually assists the system by bolusing for food intake, 5) a fully automated closed loop with insulin only, and 6) a fully automated multi-hormone closed loop system [57]. Currently, Step 1 is commercially available in Europe, Australia, and Canada (the Medtronic Veo system), and Steps 2-6 exist in research studies.

\section{Insulin delivery devices}

\section{A. Insulin pumps}

Insulin pumps are the most physiologic means currently available for insulin delivery. Advancements in technology have transformed what in 1964 was once a large piece of equipment to a small, beeper-sized device that delivers both basal and bolus insulin. User input is essential for a pump to function optimally.

Today's pumps are available in both wired (with external tubing, e.g., Animas, Medtronic MiniMed, Roche) and wireless (without external tubing, e.g., OmniPod) versions. The wired pumps are attached to the body using an infusion set. The current wireless (patch) pumps are about the size of a small computer mouse, and are attached directly to the body without any tubing in between. A small catheter is inserted subcutaneously from the underside of the patch pump by pressing a button on the remote control. This serves as the patch pump's infusion set. Today, basal rates can be titrated in as small as 0.025 -unit increments, and boluses can be given in 0.05-unit increments. Wired pumps can be detached from the site for showers, water sports, and other activities. Currently available patch pumps remain on the body and are waterproof.

Existing insulin pumps allow the user to enter their carbohydrate intake and their BG, and the pump calculates the insulin dose based on their settings. Medtronic
MiniMed and Animas both have sensor-augmented pumps available, wherein interstitial glucose readings are checked every five minutes and displayed on the pump's screen. The Medtronic MiniMed Veo, which is only available outside of the US, has an auto-shutoff feature if the sensor glucose is low and the user does not respond.

\section{Benefits}

Many studies have found better glycemic control and/or better quality of life in patients who use insulin pumps compared to those on multiple daily injections (MDI) [58-79]. However, other studies have failed to show improvement in glycemic control compared to MDI [8084]. Even without improvements in glycemic control, the quality of life benefits offered by insulin pump therapy are worthwhile $[85,86]$. Insulin pumps are easy to use in insulin-requiring patients of all ages, including infants [74-76].

Sensor-augmented pumps improve glycemic control, but only when the sensor is worn at least $41-60 \%$ of the time $[39,45]$. Both adult and pediatric patients with diabetes have attained metabolic benefits using these devices [46].

\section{Disadvantages}

The biggest potential downside to insulin pump therapy is being tethered to a device, and the fact that the presence of this device is a constant reminder that one has diabetes. However, few patients discontinue insulin pump therapy because of these issues [87,88]. Rapid onset of ketoacidosis (DKA) can occur within 7-8 hrs with insulin pump therapy if there is an infusion set or insulin delivery malfunction $[89,90]$ because there is no long acting insulin to provide a safety net as with MDI $[86,91]$.

\section{Future directions/under development}

Recently, there has been an explosion of new products being developed in the insulin pump market (Table 2) [31,92-105]. Companies continuously strive to improve upon existing wired insulin pumps by adding meters that double as full-service remote controls for the pump itself (Roche Accu-Chek Combo), becoming sensorenhanced with easy-to-read output on the pump's screen (Animas Vibe + the Dexcom G4 sensor), improving on the pump's hardware to make it lighter and more failsafe (Spring ADI pump), making pump therapy easier by using pre-filled insulin cartridges (Asante's Pearl pump), and improving on the size, interface, and usability of the pump (Tandem's t:slim pump).

Until recently, infusion sets have remained more or less unchanged over the past several years. Spring's newly FDA-approved 90-degree luer-lock infusion set is designed to detect site detachment by occluding the 
Table 2 Innovative new insulin pumps (existing \& under Development)

\begin{tabular}{|c|c|c|c|c|c|c|}
\hline Pump & Company & FDA/CE status & Pump type & $\begin{array}{l}\text { Reservoir } \\
\text { volume }\end{array}$ & Pros & Cons \\
\hline \multicolumn{7}{|c|}{ Wired Pumps (With Tubing) } \\
\hline $\begin{array}{l}\text { Accu-Chek } \\
\text { Combo }\end{array}$ & Roche & $\begin{array}{l}\text { FDA: approved } \\
\text { July } 2012 \text { CE: } \\
\text { approved late } \\
\text { 2009/early } 2010\end{array}$ & Wired & 315 units & Meter as full-service remote control & Text on meter remote is small \\
\hline $\begin{array}{l}\text { Animas } \\
\text { Vibe }\end{array}$ & $\begin{array}{l}\text { Animas/ } \\
\text { Johnson \& } \\
\text { Johnson }\end{array}$ & $\begin{array}{l}\text { FDA: waiting CE: } \\
\text { approved } \\
\text { June } 2011\end{array}$ & $\begin{array}{l}\text { Wired, sensor- } \\
\text { augmented }\end{array}$ & 200 units & $\begin{array}{l}\text { Sensor-augmented pump with Dexcom } \\
\text { G4 sensor }\end{array}$ & $\begin{array}{l}\text { Meter remote feature from } \\
\text { Animas One Touch Ping does } \\
\text { not exist with this pump }\end{array}$ \\
\hline $\begin{array}{l}\text { ADI pump } \\
\left(1^{\text {st }}\right. \\
\text { generation })\end{array}$ & $\begin{array}{l}\text { Spring/ } \\
\text { D-Medical }\end{array}$ & $\begin{array}{l}\text { FDA: approved } \\
\text { June } 2008 \text { CE: } \\
\text { approved } \\
\sim \text { June } 2008 \\
\end{array}$ & Wired & 300 units & Lighter and more failsafe & \\
\hline $\begin{array}{l}\text { Spring } \\
\text { Zone } \\
\text { pump } \\
\text { (2 } \\
\text { generation) }\end{array}$ & $\begin{array}{l}\text { Spring/ } \\
\text { D-Medical }\end{array}$ & $\begin{array}{l}\text { FDA: submitted, } \\
\text { waiting CE: } \\
\text { approved } \\
\text { January } 2012\end{array}$ & Wired & 300 units & $\begin{array}{l}\text { Small, light, more failsafe than } \\
\text { competitors' pumps }\end{array}$ & $\begin{array}{l}\text { Proprietary reservoir/infusion } \\
\text { set connection }\end{array}$ \\
\hline Pearl pump & $\begin{array}{l}\text { Asanti } \\
\text { Solutions }\end{array}$ & $\begin{array}{l}\text { FDA: approved } \\
\text { May } 2011 \text { CE: } \\
\text { approved } \\
\text { April } 2011\end{array}$ & Wired & 300 units & $\begin{array}{l}\text { Pre-filled insulin cartridges. Pump } \\
\text { designed to simplify diabetes care }\end{array}$ & Not yet available for use \\
\hline t:slim & Tandem & $\begin{array}{l}\text { FDA: approved } \\
\text { Nov. } 2011 \text { CE: } \\
\text { not yet approved }\end{array}$ & Wired & 300 units & $\begin{array}{l}\text { Slim, rechargeable power source, } \\
\text { micro-USB connectivity from } \\
\text { pump to computer }\end{array}$ & Rechargeable power source \\
\hline \multicolumn{7}{|l|}{ Patch Pumps } \\
\hline $\begin{array}{l}\text { OmniPod } \\
\text { sensor- } \\
\text { augmented } \\
\text { pump }\end{array}$ & Insulet & $\begin{array}{l}\text { FDA: submitted, } \\
\text { waiting CE: not } \\
\text { yet approved }\end{array}$ & Patch pump & 200 units & $\begin{array}{l}\text { Sensor-augmented pump; remote } \\
\text { control (PDM) doubles as BG meter; } \\
\sim 40 \% \text { smaller than current OmniPod } \\
\text { pump }\end{array}$ & Pod adhesive issues \\
\hline $\begin{array}{l}\text { Solo } \\
\text { micropump }\end{array}$ & $\begin{array}{l}\text { Medingo/ } \\
\text { Roche }\end{array}$ & $\begin{array}{l}\text { FDA: approved } \\
\text { July } 2009 \text { CE: not } \\
\text { yet approved }\end{array}$ & Patch pump & 200 units & $\begin{array}{l}\text { Detachable, has bolus buttons on the } \\
\text { side, reusable/rechargeable parts }\end{array}$ & \\
\hline $\begin{array}{l}\text { Cellnovo } \\
\text { pump }\end{array}$ & Cellnovo & $\begin{array}{l}\text { FDA: not yet } \\
\text { approved CE: } \\
\text { approved } \\
\text { Sept. } 2011\end{array}$ & $\begin{array}{l}\text { Patch pump } \\
\text { (with small } \\
\text { length of } \\
\text { external } \\
\text { tubing) }\end{array}$ & & $\begin{array}{l}\text { Detachable (?), reusable/rechargeable } \\
\text { parts, has a built-in activity sensor; } \\
\text { world's first mobile-connected diabetes } \\
\text { management system }\end{array}$ & \\
\hline Jewel & Debiotech & $\begin{array}{l}\text { FDA: application } \\
\text { filed 2010, } \\
\text { waiting CE: not } \\
\text { yet approved }\end{array}$ & Patch pump & 450 units & $\begin{array}{l}\text { Detachable, small footprint on the body, } \\
\text { bladder (flexible) insulin reservoir, works } \\
\text { with existing mobile phone platforms } \\
\text { for remote control }\end{array}$ & \\
\hline -- & $\begin{array}{l}\text { Medtronic } \\
\text { MiniMed }\end{array}$ & $\begin{array}{l}\text { FDA \& CE: not } \\
\text { yet approved }\end{array}$ & Patch pump & $\sim 200$ units & & \\
\hline Freehand & $\begin{array}{l}\text { Medsolve } \\
\text { Technologies }\end{array}$ & $\begin{array}{l}\text { FDA \& CE: not } \\
\text { yet approved }\end{array}$ & Patch pump & 300 units & & \\
\hline -—- & $\begin{array}{l}\text { Spring/ } \\
\text { D-Medical }\end{array}$ & $\begin{array}{l}\text { FDA \& CE: not } \\
\text { yet approved }\end{array}$ & Patch pump & & & \\
\hline V-Go & Valeritas & $\begin{array}{l}\text { FDA: approved } \\
\text { December } 2010 \\
\text { CE: approved } \\
\text { July } 2011\end{array}$ & Patch pump & $56-76$ units & Simple, no remote control & $\begin{array}{l}\text { Only pre-set doses allowed for } \\
\text { both basal and bolus; basal } \\
\text { rate is the same hourly rate } \\
\text { throughout the day }\end{array}$ \\
\hline Finesse & Calibra & $\begin{array}{l}\text { FDA: approved } \\
\text { January } 2010 \text { CE: } \\
\text { no information } \\
\text { available }\end{array}$ & $\begin{array}{l}\text { "Simple and } \\
\text { elegant insulin } \\
\text { delivery } \\
\text { device" }\end{array}$ & 200 units & $\begin{array}{l}\text { Simple, no remote control, allows for } \\
\text { bolus delivery only }\end{array}$ & $\begin{array}{l}\text { Can only bolus in pre-set } \\
\text { increments; no basal insulin } \\
\text { delivery }\end{array}$ \\
\hline Nanopump & Debiotech & $\begin{array}{l}\text { FDA \& CE: not } \\
\text { yet approved }\end{array}$ & $\begin{array}{l}\text { Patch pump/ } \\
\text { Nanopump }\end{array}$ & & Extremely small & \\
\hline
\end{tabular}


insulin delivery if the site should come out of the body [106].

Many companies are working on patch pumps. The proprietary nature of this information precludes completeness of this list. However, all publicly available information is outlined in Table 2. These pumps strive to improve on existing patch pump technology by being detachable (Roche/Medingo Solo, possibly Cellnovo, Debiotech Jewel, others), adding bolus buttons to the side of the patch pump so insulin can be delivered even without the remote control (Roche/Medingo Solo, others), reducing waste by having reusable or rechargeable parts (Roche/Medingo Solo, Cellnovo, others), having a smaller footprint on the body (Debiotech Jewel, others), changing the dimensions so it can hold larger amounts of insulin (Debiotech Jewel holds 450 units), and working with existing cell phone platforms so that another device does not need to be carried (Debiotech Jewel, others). Some simplistic patch pumps/insulin delivery devices that exist (Valeritas V-Go and Calibra's Finesse) are aimed more towards patients with type 2 diabetes.

Debiotech is also working on a nanopump, a tiny volumetric pump with a pair of check valves that is integrated into a MEMS chip. "The chip is a stack of three layers bonded together: a silicon on insulator (SOI) plate with micromachined pump-structures and two Pyrex cover plates with through-holes" [104].

\section{B. Inhaled insulin}

Inhaled insulin formulations have been under development for several years, and existing products are able to mimic both first- and second-phase insulin responses [107-111]. Pfizer's Exubera was available in the US market for approximately six months, but it was unsuccessful and was discontinued [112] due to large, difficult to titrate volumes that needed dispensation by a large device. Other formulations of inhaled insulin are in the works [107,113-116], and their absorption and action profiles are excellent [107-111,113-116]. Limitations of inhaled insulin include difficulty titrating the exact dose needed, potential absorption issues through alveolar and/or buccal membranes, the size of the insulin delivery device itself, and the potential of repeated insulin dosing causing hypertrophy or other problems in the lungs $[107,117,118]$. Additionally, basal insulin must still be injected despite the use of inhaled insulin.

\section{Insulin pills}

Insulin is a protein which is degraded by digestive enzymes and hence must be taken as an injection. However, by using different sized particles, coverings, and inhibitors which allow for insulin to be transported through the gastrointestinal tract, a few companies have developed an insulin pill that is taken by mouth and works like an injection of quick-acting insulin. Limitations of this preparation include that the pill must be taken on an empty stomach for proper absorption. Additionally, if the patient has a second helping of food, the second dose of the insulin pill is not effective because the food that is already in the stomach prevents its absorption [119-123]. Insulin pills are not yet FDA approved.

\section{Insulin patches/Transdermal insulin delivery}

Transdermal insulin delivery allows insulin to be absorbed through the skin and can be given anywhere on the body, regardless of the body composition of the person with diabetes. Insulin patches can be potentially used with both rapid-acting and long-acting insulins [124-126]. However, no matter which insulin is put into the patch, all insulin patches have worked like basal insulin until recently [127]. Insulin patches are not yet commercially available.

\section{E. Smart insulin}

Initially a creation of a nanotechnology scientist from MIT and now being developed by Merck, SmartInsulin is an insulin that has been chemically modified to release insulin in response to glucose in the bloodstream. The chemical component attached to the insulin, a biodegradable polymer containing sticky sugar groups, causes it to remain insoluble in the body until a certain concentration of glucose is reached. The glucose then attracts the components that make the insulin insoluble, pulling them away from the hormone and allowing it to become active. It is believed that this will allow for better postprandial insulin coverage while minimizing the incidence of hypoglycemia, all with only one injection per day $[128,129]$. SmartInsulin is still in preclinical studies.

\section{Conclusion}

We are in the midst of a revolution of technological advancements in diabetes care. This technology boom and associated variety of diabetes management tools enable clinicians to develop new and innovative means of treating their patients. Additionally, these advancements have the potential to decrease the burden of diabetes management on the patients themselves. Advances in diabetes technology will continue to improve patient care and its delivery, and may one day lead to fully automated treatment systems for people with diabetes mellitus.

\section{Abbreviations}

BG: Blood glucose; FDA: Food and Drug Administration; US: United States; PDM: Personal Diabetes Manager; CGM: Continuous glucose monitoring; RTCGM: Real-time continuous glucose monitoring; JDRF: Juvenile Diabetes 
Research Foundation; MDI: Multiple daily injections; DKA: Diabetic ketoacidosis; MEMS: Micro-Electro-Mechanical Systems; MIT: Massachusetts Institute of Technology (Cambridge, MA).

\section{Competing interests}

The authors of this article do not have any conflicts of interest to disclose. NR was on the Educator Advisory Panel for Medingo (now a division of Roche) from 9/06 - 6/11, and is currently on the Educator Advisory Boards for both Unomedical and Halozyme. Both authors are working on an $\mathrm{NIH}$ funded project with the Medtronic MiniMed ePID closed loop system.

\section{Authors' contributions}

NR researched the material, wrote the paper, and created the tables. RAH confirmed the research and edited the manuscript. Both authors read and approved the final manuscript.

\section{Authors' informations}

Neesha Ramchandani, PNP, CDE is a Pediatric Nurse Practitioner in Diabetes at the Children's Hospital of Montefiore in the Bronx, NY, USA. Neesha has a strong interest in both diabetes technology and pediatric diabetes. She has published many papers on diabetes technology, including the first paper in the literature on insulin pumps from the time of diagnosis of type 1 diabetes without any additional agent and the first paper in the literature on why people do not use glucose sensors. Neesha has presented her work around the world, including in the United States, many countries in Europe, Turkey, South Africa, and Israel. She is currently involved in research using the closed loop/artificial pancreas system.

Rubina A. Heptulla, MD is the Chief of the Division of Pediatric Endocrinology \& Diabetes at the Children's Hospital of Montefiore and Professor of Medicine at Albert Einstein College of Medicine, both in the Bronx, NY, USA. Dr. Heptulla is the author of numerous publications in the area of pediatric type 1 diabetes and is an NIH funded researcher for many years.

Received: 17 August 2012 Accepted: 15 October 2012 Published: 26 October 2012

\section{References}

1. Health D: Blood Glucose Meters.; 2012. available from http://www. diabeteshealth.com/media/pdfs/PRG0112/BloodGlucoseMeters.pdf). 2012, pp. table of currently available BG meters.

2. Ginsberg BH: Factors affecting blood glucose monitoring: sources of errors in measurement. J Diabetes Sci Technol 2009, 3:903-913.

3. Lyon ME, Baskin LB, Braakman S, Presti S, Dubois J, Shirey T: Interference studies with two hospital-grade and two home-grade glucose meters. Diabetes Technol Ther 2009, 11:641-647.

4. Heinemann L: Quality of glucose measurement with blood glucose meters at the point-of-care: relevance of interfering factors. Diabetes Technol Ther 2010, 12:847-857.

5. Freestyle InsuLinx website: Freestyle InsuLinx website. available from http://www.abbottdiabetescare.co.uk/your-products/freestyle-insulinx.

6. Meet the meter that actually wants to get to know you better. 2012. available from http://www.onetouch.com/verio.

7. DiabetesNet. HealthPia Glucophone. 2011. available from http://www. diabetesnet.com/node/303.

8. GlucoTel Makes Glucose Monitoring Easy. available from http://www.bodytel. com/en/patient/products/glucotel.html.

9. iBG Star website. available from http://www.bgstar.com/web/ibgstar.

10. InDuo website. available from http://www.lifescan.com/company/about/ press/prinduo/.

11. Brighter One website. available from http://www.brightercompany.com/ video). pp. combination BG meter and insulin pen.

12. Numerous Non-Invasive Glucose Monitors Under Development. 2011. available from http://www.bigmountaindrugs.com/blog/index.php/2011/05/ numerous-non-invasive-glucose-monitors-under-development/). May 11.

13. Telcare website. available from http:/telcare.com/.

14. Telcare connectivity information. available from http://mobihealthnews.com/ 12226/fda-clears-telcares-3g-blood-glucose-meter/.

15. GlucoTrack website. available from http://www.integrity-app.com/description. html.
16. In A T. The tiny tattoo that could (monitor blood sugar in florescent light). Edited by Tendrich A. 2011. accessed from http://www.diabetesmine.com/ 2011/08/the-tiny-tattoo-that-could-monitor-blood-sugar-in-florescent-light. html).

17. J V. Fluorescent nanosensor tattoo monitors glucose under the iPhone's glare. 2011. available from http://www.engadget.com/2011/07/21/fluorescentnanosensor-tattoo-monitors-glucose-under-the-iphone/.

18. Grove Instruments website. available from http://groveinstruments.com/.

19. Grove Instruments technology. available from http://groveinstruments.com/ grovetechnology.html.

20. InLight Solutions website. available from http://www.inlightsolutions.com/ prod-glu.html.

21. LighTouch website. available from http://www.lightouchmedical.com/ glucosemonitor.html.

22. I-Sugarx website. available from http://www.freedom-meditech.com/index. php?submenu=Endo\&src=gendocs\&ref=Professional\%20-\%20Common\% 20GM\%20Product\%20Description\&category=Professional.

23. BA P. Augmented Reality in a Contact Lens ieee spectrum: BA P. Augmented Reality in a Contact Lens ieee spectrum.; 2009. available from http://spectrum. ieee.org/biomedical/bionics/augmented-reality-in-a-contact-lens/0.

24. Tura A, Maran A, Pacini G: Non-invasive glucose monitoring: assessment of technologies and devices according to quantitative criteria. Diabetes Res Clin Pract 2007, 77:16-40.

25. Diabetech (R) Launches GlucoMON (R)-RT Real-Time Monitoring for Remote Diabetes Caregivers. 2008. available from http://www.prweb.com/releases/ 2008/02/prweb678523.htm). Feb. 6.

26. G O. GlucoMon Remote Diabetic Monitoring medGadget. 2008. available from http://medgadget.com/2008/02/glucomon_remote_diabetic_monitoring. html). Feb. 7.

27. Cerner online diabetes tool. available from http://www.openclinical.org/publicApp_CernerDiabetes.

28. Diasend website. available from http://diasend.com/site/index.php? option=com_content\&task=view\&id=12\&ltemid=105\&lang=en.

29. CareLink Personal Therapy Management Software for Diabetes. available from carelink.minimed.com.

30. Mamkin I, Ten S, Bhandari S, Ramchandani N: Real-time continuous glucose monitoring in the clinical setting: the good, the bad, and the practical. J Diabetes Sci Technol 2008, 2:882-889.

31. Kovatchev BP, Gonder-Frederick LA, Cox DJ, Clarke WL: Evaluating the accuracy of continuous glucose-monitoring sensors: continuous glucoseerror grid analysis illustrated by TheraSense Freestyle Navigator data. Diabetes Care 2004, 27:1922-1928.

32. Bode B, Gross K, Rikalo N, Schwartz S, Wahl T, Page C, et al: Alarms based on real-time sensor glucose values alert patients to hypo- and hyperglycemia: the guardian continuous monitoring system. Diabetes Technol Ther 2004, 6:105-113.

33. Gandrud LM, Xing D, Kollman C, Block JM, Kunselman B, Wilson DM, et al: The Medtronic Minimed Gold continuous glucose monitoring system: an effective means to discover hypo- and hyperglycemia in children under 7 years of age. Diabetes Technol Ther 2007, 9:307-316.

34. Diabetes Research in Children Network Study G: The accuracy of the CGMS in children with type 1 diabetes: results of the diabetes research in children network (DirecNet) accuracy study. Diabetes Technol Ther 2003, 5:781-789.

35. Garg S, Zisser H, Schwartz S, Bailey T, Kaplan R, Ellis S, et al: Improvement in glycemic excursions with a transcutaneous, real-time continuous glucose sensor: a randomized controlled trial. Diabetes Care 2006, 29:44-50.

36. Maia FF, Araujo LR: [Accuracy, utility and complications of continuous glucose monitoring system (CGMS) in pediatric patients with type 1 diabetes]. J Pediatr 2005, 81:293-297.

37. Deiss D, Bolinder J, Riveline JP, Battelino T, Bosi E, Tubiana-Rufi N, et al: Improved glycemic control in poorly controlled patients with type 1 diabetes using real-time continuous glucose monitoring. Diabetes Care 2006, 29:2730-2732.

38. Bailey TS, Zisser HC, Garg SK: Reduction in hemoglobin A1C with real-time continuous glucose monitoring: results from a 12-week observational study. Diabetes Technol Ther 2007, 9:203-210.

39. Hirsch IB, Abelseth J, Bode BW, Fischer JS, Kaufman FR, Mastrototaro J, et al: Sensor-augmented insulin pump therapy: results of the first randomized treat-to-target study. Diabetes Technol Ther 2008, 10:377-383. 
40. Juvenile Diabetes Research Foundation Continuous Glucose Monitoring, Study G, Tamborlane WW, Beck RW, Bode BW, Buckingham B, Chase HP, et al: Continuous glucose monitoring and intensive treatment of type 1 diabetes. N Engl J Med 2008, 359:1464-1476.

41. Raccah D, Sulmont V, Reznik Y, Guerci B, Renard E, Hanaire H, et al: Incremental value of continuous glucose monitoring when starting pump therapy in patients with poorly controlled type 1 diabetes: the RealTrend study. Diabetes Care 2009, 32:2245-2250.

42. T D: Continuous glucose monitoring. New Orleans, LA: American Diabetes Association 69th Scientific Sessions; 2009.

43. Diabetes Research in Children Network, Study G, Buckingham B, Beck RW, Tamborlane W, Xing D, Kollman C, et al: Continuous glucose monitoring in children with type 1 diabetes. J Pediatr 2007, 151:388-393. 93 e1-2.

44. Diabetes Research in Children Network, Study G, Weinzimer S, Xing D, Tansey M, Fiallo-Scharer R, Mauras N, et al: Prolonged use of continuous glucose monitors in children with type 1 diabetes on continuous subcutaneous insulin infusion or intensive multiple-daily injection therapy. Pediatr Diabetes 2009, 10:91-96.

45. Bergenstal RM, Tamborlane WW, Ahmann A, Buse JB, Dailey G, Davis SN, et al: Effectiveness of sensor-augmented insulin-pump therapy in type 1 diabetes. N Engl J Med 2010, 363:311-320.

46. Bergenstal RM, Tamborlane W, Ahmann A, Buse JB, Dailey G, Davis SN, et al: Sensor-augmented pump therapy for $A 1 C$ reduction (STAR 3) study: results from the 6-month continuation phase. Diabetes Care 2011, 34:2403-2405.

47. Ramchandani N, Arya S, Ten S, Bhandari S: Real-life utilization of real-time continuous glucose monitoring: the complete picture. J Diabetes Sci Technol 2011, 5:860-870.

48. Symphony tCGM system. available from http://www.echotx.com/symphonytcgm-system.shtml.

49. Prelude system. (available from http://www.echotx.com/prelude-skinprepsystem.shtml). pp. Prelude is used with the Symphony tCGM system to prep the skin.

50. Solianis/Biovotion AG website. available from http://www.biovotion.com/ technology-parameters-multisensor.phtml.

51. Saxl T, Khan F, Ferla M, Birch D, Pickup J: A fluorescence lifetime-based fibre-optic glucose sensor using glucose/galactose-binding protein. Analyst 2011, 136:968-972

52. Conference Proceedings: In Ninth Annual Diabetes Technology Meeting, San Francisco, CA. Edited by D K: 2009.

53. Wang W, Li Z, Zheng W, Dong B, Li S, Wang C: A novel non-enzymatic glucose sensor based on nickel (II) oxide electrospun nanofibers. J Nanosci Nanotechnol 2010, 10:7537-7540.

54. Nie H, Yao Z, Zhou X, Yang Z, Huang S: Nonenzymatic electrochemical detection of glucose using well-distributed nickel nanoparticles on straight multi-walled carbon nanotubes. Biosens Bioelectron 2011 30:28-34.

55. Johannessen E, Krushinitskaya O, Sokolov A, Philipp H, Hoogerwerf A, Hinderling C, et al: Toward an injectable continuous osmotic glucose sensor. J Diabetes Sci Technol 2010, 4:882-892.

56. Joseph Il, Hipszer B: Real-time glucose monitoring in the hospital: future or now? Adv Surg 2010, 44:165-184.

57. Kowalski AJ: Can we really close the loop and how soon? Accelerating the availability of an artificial pancreas: a roadmap to better diabetes outcomes. Diabetes Technol Ther 2009, 11(Suppl 1):S113-S119.

58. Tamborlane $\mathrm{W}$ : Fulfilling the promise of insulin pump therapy in childhood diabetes. Pediatr Diabetes 2006, 7(Suppl 4):4-10.

59. Willi SM, Planton J, Egede L, Schwarz S: Benefits of continuous subcutaneous insulin infusion in children with type 1 diabetes. J Pediat 2003, 143:796-801.

60. Boland EA, Grey M, Oesterle A, Fredrickson L, Tamborlane WV: Continuous subcutaneous insulin infusion. A new way to lower risk of severe hypoglycemia, improve metabolic control, and enhance coping in adolescents with type 1 diabetes. Diabetes Care 1999, 22:1779-1784

61. Sulli N, Shashaj B: Long-term benefits of continuous subcutaneous insulin infusion in children with Type 1 diabetes: a 4-year follow-up. Diabet Med J Br Diabet Assoc 2006, 23:900-906.

62. Jakisch BI, Wagner VM, Heidtmann B, Lepler R, Holterhus PM, Kapellen TM, et al: Comparison of continuous subcutaneous insulin infusion (CSII) and multiple daily injections (MDI) in paediatric Type 1 diabetes: a multicentre matched-pair cohort analysis over 3 years. Diabet Med J Br Diabet Assoc 2008, 25:80-85.

63. Scrimgeour L, Cobry E, McFann K, Burdick P, Weimer C, Slover R, et al: Improved glycemic control after long-term insulin pump use in pediatric patients with type 1 diabetes. Diabetes Technol Ther 2007, 9:421-428.

64. Danne T, von Schutz W, Lange K, Nestoris C, Datz N, Kordonouri O: Current practice of insulin pump therapy in children and adolescents - the Hannover recipe. Pediatr Diabetes 2006, 7(Suppl 4):25-31.

65. Tamborlane W, Sikes KA, Steffen AT, Weinzimer SA: Continuous subcutaneous insulin infusion (CSII) in children with type 1 diabetes. Diabetes Res Clin Pract 2006, 74(Suppl 2):S112-S115.

66. Tamborlane $W$, Fredrickson $L P$, Ahern $J H$ : Insulin pump therapy in childhood diabetes mellitus: guidelines for use. Treat Endocrinol 2003, 2:11-21.

67. Pickup JC, Sutton AJ: Severe hypoglycaemia and glycaemic control in Type 1 diabetes: meta-analysis of multiple daily insulin injections compared with continuous subcutaneous insulin infusion. Diabet Med J Br Diabet Assoc 2008, 25:765-774.

68. Hanas R, Adolfsson P: Insulin pumps in pediatric routine care improve long-term metabolic control without increasing the risk of hypoglycemia. Pediatr Diabetes 2006, 7:25-31.

69. Danne T, Battelino T, Kordonouri O, Hanas R, Klinkert C, Ludvigsson J, et al: A cross-sectional international survey of continuous subcutaneous insulin infusion in 377 children and adolescents with type 1 diabetes mellitus from 10 countries. Pediatr Diabetes 2005, 6:193-198.

70. Doyle EA, Weinzimer SA, Steffen AT, Ahern JA, Vincent M, Tamborlane WV A randomized, prospective trial comparing the efficacy of continuous subcutaneous insulin infusion with multiple daily injections using insulin glargine. Diabetes Care 2004, 27:1554-1558.

71. Jeha GS, Karaviti LP, Anderson B, Smith EO, Donaldson S, McGirk TS, et al Insulin pump therapy in preschool children with type 1 diabetes mellitus improves glycemic control and decreases glucose excursions and the risk of hypoglycemia. Diabetes Technol Ther 2005, 7:876-884

72. Saha ME, Huuppone T, Mikael K, Juuti M, Komulainen J: Continuous subcutaneous insulin infusion in the treatment of children and adolescents with type 1 diabetes mellitus. J Pediatr Endocrinol Metab JPEM 2002, 15:1005-1010.

73. Shehadeh N, Battelino T, Galatzer A, Naveh T, Hadash A, de Vries L, et al: Insulin pump therapy for 1-6 year old children with type 1 diabetes. Israel Med Assoc J IMAJ 2004, 6:284-286.

74. Weinzimer SA, Doyle EA, Steffen AT, Sikes KA, Tamborlane W: Rediscovery of insulin pump treatment of childhood type 1 diabetes. Minerva Med 2004, 95:85-92.

75. Weinzimer SA, Ahern JH, Doyle EA, Vincent MR, Dziura J, Steffen AT, et al: Persistence of benefits of continuous subcutaneous insulin infusion in very young children with type 1 diabetes: a follow-up report. Pediatrics 2004, 114:1601-1605.

76. Maahs DM, Horton LA, Chase HP: The use of insulin pumps in youth with type 1 diabetes. Diabetes Technol Ther 2010, 12(Suppl 1):S59-S65.

77. Danne T, Battelino T, Jarosz-Chobot P, Kordonouri O, Pankowska E, Ludvigsson J, et al: Establishing glycaemic control with continuous subcutaneous insulin infusion in children and adolescents with type 1 diabetes: experience of the PedPump Study in 17 countries. Diabetologia 2008, 51:1594-1601.

78. Pickup J: Insulin pumps. In International journal of clinical practice Supplement: 2011:16-19.

79. Pickup JC, Renard E: Long-acting insulin analogs versus insulin pump therapy for the treatment of type 1 and type 2 diabetes. Diabetes Care 2008, 31(Suppl 2):S140-S145.

80. DiMeglio LA, Pottorff TM, Boyd SR, France L, Fineberg N, Eugster EA: A randomized, controlled study of insulin pump therapy in diabetic preschoolers. J Pediatr 2004, 145:380-384

81. Weintrob N, Benzaquen H, Galatzer A, Shalitin S, Lazar L, Fayman G, et al: Comparison of continuous subcutaneous insulin infusion and multiple daily injection regimens in children with type 1 diabetes: a randomized open crossover trial. Pediatrics 2003, 112:559-564.

82. Wilson DM, Buckingham BA, Kunselman EL, Sullivan MM, Paguntalan HU, Gitelman SE: A two-center randomized controlled feasibility trial of insulin pump therapy in young children with diabetes. Diabetes Care 2005, 28:15-19. 
83. Nabhan ZM, Kreher NC, Greene DM, Eugster EA, Kronenberger W, DiMeglio $L A$ : A randomized prospective study of insulin pump vs. insulin injection therapy in very young children with type 1 diabetes: 12-month glycemic, BMI, and neurocognitive outcomes. Pediatr Diabetes 2009, 10:202-208

84. Shalitin S, Phillip M: The use of insulin pump therapy in the pediatric age group. Horm Res 2008, 70:14-21.

85. Bode BW, Tamborlane W, Davidson PC: Insulin pump therapy in the 21st century. Strategies for successful use in adults, adolescents, and children with diabetes. Postgrad Med 2002, 111:69-77. quiz 27.

86. Bode BW, Sabbah HT, Gross TM, Fredrickson LP, Davidson PC: Diabetes management in the new millennium using insulin pump therapy. Diabetes Metab Res Rev 2002, 18(Suppl 1):S14-S20.

87. Hofer SE, Heidtmann B, Raile K, Frohlich-Reiterer E, Lilienthal E, Berghaeuser $M A$, et al: Discontinuation of insulin pump treatment in children, adolescents, and young adults. A multicenter analysis based on the DPV database in Germany and Austria. Pediatr Diabetes 2010, 11:116-121.

88. de Vries L, Grushka Y, Lebenthal Y, Shalitin S, Phillip M: Factors associated with increased risk of insulin pump discontinuation in pediatric patients with type 1 diabetes. Pediatr Diabetes 2011, 12:506-512.

89. Attia N, Jones TW, Holcombe J, Tamborlane W: Comparison of human regular and lispro insulins after interruption of continuous subcutaneous insulin infusion and in the treatment of acutely decompensated IDDM. Diabetes Care 1998, 21:817-821.

90. Reichel A, Rietzsch H, Kohler HJ, Pfutzner A, Gudat U, Schulze J: Cessation of insulin infusion at night-time during CSII-therapy: comparison of regular human insulin and insulin lispro. Exp Clin Endocrinol Diabet Offic $J$ German Soc Endocrinol German Diabet Assoc 1998, 106:168-172.

91. Egger M, Davey Smith G, Stettler C, Diem P: Risk of adverse effects of intensified treatment in insulin-dependent diabetes mellitus: a meta-analysis. Diabet Med J Brit Diabet Assoc 1997, 14:919-928.

92. Animas Vibe website. available from http://animascorp.co.uk/animasVibe.

93. Spring Zone pump website. available from http://www.springnow.com/index. aspx?id=4161.

94. M A. Eight New Diabetes Products to Look For in 2012. 2011. available from http://asweetlife.org/a-sweet-life-staff/featured/eight-new-diabetes-productsto-look-for-in-2012/23195/.

95. Tandem Diabetes website. available from http://www.tandemdiabetes.com/.

96. Solo website. available from http://www.solo4you.com/.

97. Cellnovo website. available from http://www.cellnovo.com/products.aspx.

98. Jewel PUMP Value for Life. available from http://www.debiotech.com/ products/msys/insulinpump.html.

99. CNBC video: Medtronic CEO on Diabetes. available from http://video.cnbc com/gallery/?video $=1145719342$.

100. A T. Chasing the OmniPod: Patch Me If You Can. 2010. available from http://www.diabetesmine.com/2010/01/chasing-the-omnipod-patch-me-ifyou-can.html.

101. H T. Spring - A Patch Pump Without a Motor. London, England, UK: Advanced Technologies \& Treatments for Diabetes; 2011. accessed at http://www.springnow.com/uploadimages/ Spring_Hybrid_Patch_Pump_ATTD_tech_presentation.pdf.

102. V-Go website. available from http://www.valeritas.com/vgo.shtml.

103. Finesse website. available from http://www.myfinesse.com/.

104. Debiotech nanopump website. available from http://www.debiotech.com/ products/msys/chronojet.html.

105. Anhalt $\mathrm{H}$, Bohannon NJ: Insulin patch pumps: their development and future in closed-loop systems. Diabetes Technol Ther 2010, 12(Suppl 1):S51-S58

106. Spring Universal Infusion Set. available from http://www.springnow.com/ infusion-set.html.

107. Mastrandrea LD: Inhaled insulin: overview of a novel route of insulin administration. Vasc Health Risk Manag 2010, 6:47-58.

108. Harsch IA: Inhaled insulins: their potential in the treatment of diabetes mellitus. Treat Endocrinol 2005, 4:131-138.

109. Becquemin $\mathrm{MH}$, Chaumuzeau JP: Inhaled insulin: a model for pulmonary systemic absorption? Rev Mal Respir 2010, 27:e54-e65.

110. Heinemann L: New ways of insulin delivery. In International journal of clinical practice Supplement. 2011:31-46.

111. Potocka E, Baughman RA, Derendorf H: Population pharmacokinetic model of human insulin following different routes of administration. J Clin Pharmacol 2011, 51:1015-1024.
112. Inhaled insulin no longer marketed: discontinuation: Welcome news. Prescrire Int 2008, 17:139.

113. Neumiller JJ, Campbell RK, Wood LD: A review of inhaled technosphere insulin. Ann Pharmacother 2010, 44:1231-1239.

114. Hisasue J, Fukuyama S, Nakagaki N, Moriwaki A, Inoue S, Sakurada N, et al: Inhalative administration of insulin using a new bubble jet atomization device. Fukuoka lgaku Zasshi Hukuoka Acta Med 2011, 102:215-222.

115. Depreter F, Burniat A, Blocklet D, Lacroix S, Cnop M, Fery F, et al: Comparative pharmacoscintigraphic and pharmacokinetic evaluation of two new formulations of inhaled insulin in type 1 diabetic patients. Eur $J$ Pharm Biopharm Offic J Arbeitsgemeinschaft fur Pharmazeutische Verfahrenstechnik eV 2012, 80:4-13.

116. Pozzilli P, Raskin P, Parkin CG: Review of clinical trials: update on oral insulin spray formulation. Diabetes Obes Metab 2010, 12:91-96.

117. Warnken M, Reitzenstein U, Sommer A, Fuhrmann M, Mayer P, Enzmann H, et al: Characterization of proliferative effects of insulin, insulin analogues and insulin-like growth factor-1 (IGF-1) in human lung fibroblasts. Naunyn Schmiedebergs Arch Pharmacol 2010, 382:511-524.

118. Lasagna-Reeves CA, Clos AL, Midoro-Hiriuti T, Goldblum RM, Jackson GR, Kayed R: Inhaled insulin forms toxic pulmonary amyloid aggregates. Endocrinology 2010, 151:4717-4724.

119. R E, E A, Y M, M K: Evaluation of the safety and efficacy of two oral insulin formulations in healthy volunteers (poster presentation). Burlingame, CA: Eleventh Annual Diabetes Technology Meeting; 2011.

120. Clement S, Dandona P, Still JG, Kosutic G: Oral modified insulin (HIM2) in patients with type 1 diabetes mellitus: results from a phase I/II clinical trial. Metab Clin Exp 2004, 53:54-58.

121. Card JW, Magnuson BA: A review of the efficacy and safety of nanoparticle-based oral insulin delivery systems. Am J Physiol Gastrointest Liver Physiol 2011, 301:G956-G967.

122. Wong TW: Design of oral insulin delivery systems. J Drug Target 2010, 18:79-92.

123. Yadav N, Morris G, Harding SE, Ang S, Adams GG: Various non-injectable delivery systems for the treatment of diabetes mellitus. Endocr Metab Immune Disord Drug Targets 2009, 9:1-13.

124. Rastogi R, Anand S, Koul V: Electroporation of polymeric nanoparticles: an alternative technique for transdermal delivery of insulin. Drug Dev Ind Pharm 2010, 36:1303-1311.

125. Prelude SkinPrep system website. (available from http://www.echotx.com/ drug-delivery.shtml). pp. skin prep for insulin patches.

126. Drug delivery in diabetes: making effective treatment tolerable ONdrugDELIVERY. available from http://www.ondrugdelivery.com/ publications/diabetes.pdf.

127. Qin G, Gao Y, Wu Y, Zhang S, Qiu Y, Li F, et al: Simultaneous basal-bolus delivery of fast-acting insulin and its significance in diabetes management. Nanomed Nanotechnol Biol Med 2012, 8:221-227.

128. J C. Smart insulin: J C. Smart insulin. 2008. available from http://www.technologyreview.com/biomedicine/21613/page1/.

129. A N. Merck acquires diabetes specialist SmartCells for smart insulin tech. 2010 available from http://www.smartplanet.com/blog/smart-takes/merckacquires-diabetes-specialist-smartcells-for-smart-insulin-tech/12731.

\section{doi:10.1186/1687-9856-2012-28}

Cite this article as: Ramchandani and Heptulla: New technologies for diabetes: a review of the present and the future. International Journal of Pediatric Endocrinology 2012 2012:28. 